\title{
Correlation of the Rates of Solvolysis of Diphenylthiophosphinyl Chloride Using an Extended form of the Grunwald-Winstein Equation
}

\author{
Han Joong Koh," Suk Jin Kang, and Denuis N. Kevill ${ }^{\dagger}$ \\ Department of Science Education, Chonin National University of Education, Chonin 560-759, Korea. "E-mail: hankoh(ainue.ac.kr \\ ${ }^{\dagger}$ Department of Chemisty and Biochemistry, Northern Illinois University, DeKalb, Illinois, U.S.A. \\ Received July: 26, 2008
}

\begin{abstract}
Rate of solvolysis of diphenylthiophosphinyl chloride in ethanol, methanol, and aqueous binary mixtures incorporating ethanol, methanol, acetone, 2,2,2-trifluoroethanol (TFE) or 1,1,1,3,3,3-hexafluoro-2-propanol (HFIP) are reported. Solvolyses were also carried out in TFE-ethanol mixtures. For five representative solvents, studies were made at several temperatures and activation parameters detemined. The 29 solvents gave a reasonably precise extended Grunwald-Winstein equation plot, correlation coefficient (R) of 0.933 , which improved to 0.983 when the four TFE-ethanol points were excluded. The sensitivities $(l=1.00$ and $m=0.64)$ were similar to those obtained for dimethyl phosphorochloridate and phosphorochloridotlionate and diphenylphosphinyl chloride (1). As with the four previously studied solvolyses, an $S_{\wedge} 2$ pathway is proposed for the solvolyses of diphenylthiophosphinyl chloride. The activation parameters, $\Delta \mathrm{H}^{F}$ and $\Delta \mathrm{S}^{x}$, were determined and they are also in line with values expected for an $S_{\Lambda} 2$ reaction.
\end{abstract}

Key Words : Diphenylthiophosphinyl chloride, Extended Grunwald-Winstein equation, $S_{\aleph} 2$ pathway

\section{Introduction}

Phosphoryl transfer is an important aspect of biological chemistry and organic syntheses. ${ }^{1}$ The mechanism of phosphoryl transfer from phosphate monoesters and diesters has been the subject of many recent investigations. ${ }^{2}$ In particular a considerable amount of work has been devoted to elucidating the problem of whether the reaction proceeds through a pentacoordinate phosphorane intermediate or concertedly with a single transition state (TS). ${ }^{3}$ The mechanism of reaction of phosphinothioyl compounds, such as of the diphenylthiophosphinyl chloride ( $\mathrm{Ph}_{2} \mathrm{PSCl}, 1$ ), has been less studied, in spite of their importance as highly reactive chemical intermediates. There has been a recent mechanistic study of the reaction with pyridine in acetonitrile as solvent. ${ }^{3 i}$

Previous studies by Kevill and co-workers have been of diaryl $\mathrm{l}^{+}$and dimethyl $\mathrm{l}^{5}$ phosphorochloridates, (RO) $\mathrm{POCl}$, the sulfur-for-oxygen substituted dimethyl phosphorochloridothionate, (MeO) ${ }_{2} \mathrm{PSCl},{ }^{5} N_{i} N_{,} N^{\prime}, N^{\prime}$-tetramethyldiamidophosphorochloridate, $\left(\mathrm{Me}_{2} \mathrm{~N}_{2} \mathrm{POCl}{ }^{6}\right.$ and diphenylphosphinyl chloride, $\mathrm{Ph}_{2} \mathrm{POCl}^{7}$ The extended Grunwald-Winstein equation plot for solvolyses of stated most substrates containing the P-atom as the reaction center, eq. (1), led, except for the poorly correlated solvolyses of diaryl phosphorochloridates, with phenyl or p-chlorophenyl as the aryl group, ${ }^{+}$to acceptable correlations, with very similar $/$ and $m$ values.

The Grunwald-Winstein equation in its original form ${ }^{8}$ correlates the rates of solvolysis of ionization reactions against the solvent ionizing power values." Whereas the Hammett equation involves changes in a remote substituent under otherwise constant conditions, this equation involves changes in the solvent composition under otherwise constant conditions. The Grunwald-Winstein equation can be extended to cover reactions in which the solvent also acts as a nucleophile by the addition of a second term, involving a scale of solvent nucleophilicity. ${ }^{l 1}$ This is the same basic philosophy as in the Taft equation, which extends the Hammett equation by adding a second term involving a scale of steric parameters.

The extended Grunwald-Winstein equation can be expressed as in eq. (1). In eq. (1), $k$ and $k_{o}$ represent the specific rates of solvolysis of a substrate $\mathrm{RX}$ in a given solvent and in the standard solvent ( $80 \%$ ethanol), respectively, $l$ is the sensitivity of the solvolysis to changes in solvent nucleophilicity $\left(\mathrm{N}_{\mathrm{T}}\right)^{1(1)}, m$ is the sensitivity of the solvolysis to changes in solvent in solvent ionizing power $\left(\mathrm{Y}_{\mathrm{X}}\right.$, for a leaving group $\mathrm{X})^{y}$; and $\mathrm{c}$ is a constant (residual) term.

$$
\log \left(k / k_{0}\right)=l \mathrm{~N}_{\mathrm{T}}+m \mathrm{YX}_{\mathrm{X}}+\mathrm{c}
$$

In this work, we have attempted to investigate the reaction mechanism involved in the solvolysis of diphenylthiophosphinyl chloride $\left(\mathrm{Ph}_{2} \mathrm{PSCl}, 1\right)$, with a variety of pure and mixed solvents at $55.0^{\circ} \mathrm{C}$, eq. (2), by determining on the magnitudes of the $l$ and $m$ of the extended GrunwaldWinstein equation, eq. 1. Further evidence is obtained from the activation parameters and the kinetic solvent deuterium isotope effect.

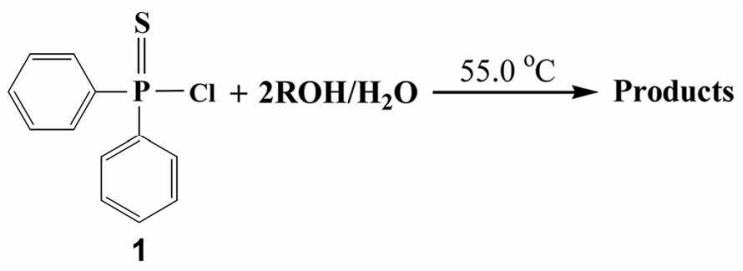

The study can be used to help to clarify the phosphoryl transfer mechanism, and to compare the reactivity with that of diphenylphosphinyl chloride $\left(\mathrm{Ph}_{2} \mathrm{POCl}, 2\right){ }^{7}$ and chloro diphenylphosphine $\left(\mathrm{Ph}_{2} \mathrm{PCl}, 3\right)^{11}$ 
<smiles>O=P(Cl)(c1ccccc1)c1ccccc1</smiles>

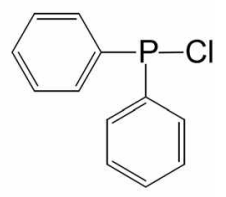

3

\section{Results and Discussion}

The specific rates of solvolysis of diphenylthiophosphiny! chloride $\left(\mathrm{Ph}_{2} \mathrm{PSCl}, 1\right)$ have been determined in 29 solvents at $55.0^{\circ} \mathrm{C}$. The solvents consisted of ethanol, methanol, and binary mixtures of water with ethanol, methanol, acetone. 2,2,2-trifluoroethanol (TFE), 1,1,1,3,3,3-hexafluoro-2-propanol (HFIP), and four binary mixtures of TFE and ethanol.

Table 1. Specific rates of solvolysis $(k)$ of diphenylthiophosphinyl chloride ( $\mathrm{Ph}, \mathrm{PSCl}, 1)^{\text {rf }}$ at $55.0^{\circ} \mathrm{C}$ and $\mathrm{N}_{T}$ and $\mathrm{Y}_{\mathrm{Cl}}$ values of the solvents

\begin{tabular}{|c|c|c|c|}
\hline Solvent ${ }^{h}$ & $10^{3} \mathrm{k}^{\prime}\left(\mathrm{s}^{-1}\right)$ & $\mathrm{N}$ & $\mathrm{Yd}$ \\
\hline $100 \% \mathrm{EtOH}$ & $0.701=0.011$ & 0.37 & -2.52 \\
\hline $90 \% \mathrm{EtOH}$ & $4.47=0.02$ & 0.16 & -0.94 \\
\hline $80 \% \mathrm{EtOH}$ & $8.58=0.04$ & 0.0 & 0.0 \\
\hline $70 \% \mathrm{EtOH}$ & $14.8=0.6$ & -0.20 & 0.78 \\
\hline $60 \% \mathrm{EtOH}$ & $23.8=0.6$ & -0.38 & 1.38 \\
\hline $50 \% \mathrm{EtOH}$ & $34.7=0.4$ & -0.58 & 2.02 \\
\hline $100 \% \mathrm{MeOH}$ & $4.31 \pm 0.04^{\prime}$ & 0.17 & -1.17 \\
\hline $90 \% \mathrm{MeOH}$ & $9.33=0.07$ & -0.01 & -0.18 \\
\hline $80 \% \mathrm{MeOH}$ & $21.4=0.6$ & -0.06 & 0.67 \\
\hline $70 \% \mathrm{MeOH}$ & $34.1=0.4$ & -0.40 & 1.46 \\
\hline $60 \% \mathrm{MeOH}$ & $56.9=1.0$ & -0.54 & 2.07 \\
\hline $95 \%$ Acetone & $0.0162=0.0005$ & -0.49 & -3.19 \\
\hline $90 \%$ Acetone & $0.0955=0.0006$ & -0.35 & -2.39 \\
\hline $80 \%$ Acetone & $1.19=0.02$ & -0.37 & -0.83 \\
\hline $70 \%$ Acetone & $5.01=0.03$ & -0.42 & 0.17 \\
\hline $60 \%$ Acetone & $9.12=0.05$ & -0.52 & 0.95 \\
\hline $50 \%$ Acetone & $20.9=0.4$ & -0.70 & 1.73 \\
\hline $90 \%$ TFE & $1.07=0.03$ & -2.55 & 2.85 \\
\hline $80 \%$ TFE & $3.37=0.04$ & -2.19 & 2.90 \\
\hline $70 \%$ TFE & $8.78=0.05$ & -1.98 & 2.96 \\
\hline $50 \%$ TFE & $31.6=0.5$ & -1.73 & 3.16 \\
\hline $90 \%$ HFIP & $0.167=0.002$ & -5.26 & 5.17 \\
\hline $80 \%$ HFIP & $1.06=0.03$ & -3.84 & 4.31 \\
\hline $70 \%$ HFIP & $2.88=0.04$ & -2.94 & 3.83 \\
\hline $50 \%$ HFIP & $3.16=0.05$ & -2.49 & 3.80 \\
\hline $80 \mathrm{~T}-20 \mathrm{E}^{g}$ & $0.178=0.002$ & -1.76 & 1.89 \\
\hline $60 \mathrm{~T}-40 \mathrm{E}^{g}$ & $0.331=0.003$ & -0.94 & 0.63 \\
\hline $40 \mathrm{~T}-60 \mathrm{E}^{g}$ & $0.537=0.005$ & -0.34 & -0.48 \\
\hline $20 \mathrm{~T}-80 \mathrm{E}^{g}$ & $0.714=0.006$ & 0.08 & -1.42 \\
\hline
\end{tabular}

"Unless othervise indicated, a $10^{-3} \mathrm{M}$ solution of the substrate in the indicated solvent, also containing $0.1 \% \mathrm{CH}_{3} \mathrm{CN}$ within the solvent. "On a wolume-wolume basis at $25.0^{\circ} \mathrm{C}$, except for TFE-Ho and HFIP-H-O mixtures, which are on a weight-weight basis. "With associated standard Jeviations. "Values from ref. 10 . "Values from ref. 9. Values of 2.36 $(=0.03)$ in methanol-d (MeOD), cortesponding to $k$ veor $/ h_{\mathrm{MeO}}$ value of $1.83 \pm 0.05$ [with associated standard error (Crumpler, T. B.: Yoh, J. H. Chemical Computations and Error, Wiley: New: York, 1940, p. 178)]. "T. $\mathrm{E}$ indicates TFE-EtOH mixtures.
The specific rates of solvolysis are presented in Table 1 , together with $\mathrm{N}_{\mathrm{T}}{ }^{10}$ and $\mathrm{Y}_{\mathrm{Cl}}{ }^{9}$ values. Also, the specific rates of solvolysis of 1 were not found to depend on the initial concentration of the substrate, as shown in Table 2.

For five of the solvents, specific rates of solvolysis were measured at three additional temperatures. These values are reported in Table 3 and, together with the values at $55.0^{\circ} \mathrm{C}$ from Table 1, they are used to calculate the enthalpies and entropies of activation, also reported in Table 3.

In the present paper, we are concerned with the specific rates of the solvolyses represented in eq. 2. In most solvents,

Table 2. Constancy of the specific rates of solvolysis $(k)$ of diphenylthiophosphinyl chloride ( $\mathrm{Ph} P \mathrm{PSCl}, 1$ ) with variation of the concentration of the substrate at $55.0^{\circ} \mathrm{C}$

\begin{tabular}{ccc}
\hline Solvent & [Ph.PSCl]. $\mathrm{M}^{a}$ & $10^{5} \mathrm{k}^{h}, \mathrm{~s}^{-1}$ \\
\hline \multirow{2}{*}{$100 \% \mathrm{EtOH}$} & 0.543 & $0.697 \pm 0.012$ \\
& 1.013 & $0.704=0.011$ \\
& 2.179 & $0.702 \pm 0.013$ \\
\hline \multirow{2}{*}{$80 \% \mathrm{EtOH}$} & 0.543 & $8.61 \pm 0.05$ \\
& 1.013 & $8.50 \pm 0.04$ \\
& 2.179 & $8.63 \pm 0.06$ \\
\hline \multirow{2}{*}{$50 \% \mathrm{EtOH}$} & 0.543 & $74.2 \pm 0.5$ \\
& 1.013 & $34.6 \pm 0.4$ \\
\hline
\end{tabular}

"Concentration of stock solution in $\mathrm{MeCN}$. "The $k$ values are the aierages of more than two runs and errors are standard deviations.

Table 3. Specific rates and activation parameters for the solvolysis of diphenylthiophosphinyl chloride ${ }^{\text {ir }}$ (Ph.PSCl, 1) in pure and aqueous solvents at various temperatures

\begin{tabular}{|c|c|c|c|c|}
\hline Solvent & $\begin{array}{c}\text { Temper- } \\
\text { ature } \\
\left({ }^{\circ} \mathrm{C}\right)\end{array}$ & $10^{5} \mathrm{~h}^{h}\left(\mathrm{~s}^{-1}\right)$ & $\begin{array}{c}\Delta \mathrm{H}^{\mp} \\
\left(\mathrm{kcal}^{-}\right. \\
\left.\mathrm{mol}^{-1}\right)^{\prime}\end{array}$ & $\begin{array}{c}-\Delta \mathrm{S}^{\mp} \\
\left(\mathrm{cal} \cdot \mathrm{mol}^{-1}\right. \\
\left.\mathrm{K}^{-1}\right)^{\prime}\end{array}$ \\
\hline \multirow{4}{*}{$100 \% \mathrm{EtOH}$} & 25 & $0.120=0.002$ & \multirow{4}{*}{$10.7=0.1$} & \multirow{4}{*}{$40.7=0.3$} \\
\hline & 35 & $0.216=0.003$ & & \\
\hline & 45 & $0.369=0.005$ & & \\
\hline & 55 & $0.701 \pm 0.011^{d}$ & & \\
\hline \multirow{4}{*}{$80 \% \mathrm{EtOH}^{2}$} & 25 & $1.75=0.03$ & \multirow{4}{*}{$10.0=0.1$} & \multirow{4}{*}{$37.8=0.3$} \\
\hline & 35 & $2.80=0.03$ & & \\
\hline & 45 & $5.05=0.04$ & & \\
\hline & 55 & $8.58 \pm 0.04^{4}$ & & \\
\hline \multirow{4}{*}{$100 \% \mathrm{MeOH}$} & 25 & $0.701=0.003$ & \multirow{4}{*}{$11.1=0.1$} & \multirow{4}{*}{$35.8=0.3$} \\
\hline & 35 & $1.26=0.02$ & & \\
\hline & 45 & $2.27=0.03$ & & \\
\hline & 55 & $4.31 \pm 0.04^{i}$ & & \\
\hline \multirow{4}{*}{$90 \% \mathrm{TFE}^{\prime}$} & 25 & $0.219=0.002$ & \multirow{4}{*}{$9.6=0.1$} & \multirow{4}{*}{$43.1=0.4$} \\
\hline & 35 & $0.350=0.003$ & & \\
\hline & 45 & $0.594=0.004$ & & \\
\hline & 55 & $1.07 \pm 0.03^{i}$ & & \\
\hline \multirow{4}{*}{$90 \% \mathrm{HFIP}^{\prime}$} & 25 & $0.0209=0.0004$ & \multirow{4}{*}{$12.9=0.1$} & \multirow{4}{*}{$36.7=0.3$} \\
\hline & 35 & $0.0398=0.0005$ & & \\
\hline & 45 & $0.0835=0.0003$ & & \\
\hline & 55 & $0.167 \pm 0.002^{i}$ & & \\
\hline
\end{tabular}

"A $10^{-3} \mathrm{M}$ solution of the substrate in the indicated solvent, also containing $0.1 \% \mathrm{CH}_{3} \mathrm{CN}$. "With associated standard deviation. "The activation parameters are accompanied by the standard error. "From Table 1 . "On a volume-rolume basis at $25.0^{\circ} \mathrm{C}$. On a weight-weight basis. 
the reactions were fast, and the use of an apparatus allowing a rapid response to changes in conductivity ${ }^{12,13}$ was a convenient way of following the extent of reaction as a function of time. To promote a rapid dissolution in the solvent, the substrate was usually added as a small volume of a concentrated stock solution in acetonitrile, such that the reaction solution contained about $0.1 \%$ acetonitrile.

The specific rates were observed to increase with increasing water content for binary aqueous mixtures. The specific rates of ethanolysis of 1 were lower $\left(k=1.20( \pm 0.02) \times 10^{-4}\right.$ $\mathrm{s}^{-1}$ at $25.0^{\circ} \mathrm{C}$ ) than the specific rates of ethanolysis of diphenylphosphinyl chloride ${ }^{7}\left(k=7.02( \pm 0.10) \times 10^{-3} \mathrm{~s}^{-1}\right.$ at $25.0^{\circ} \mathrm{C}$ ). This means that in the reaction of 1 , eq. (2), the solvents are somewhat loosely bound in transition state (TS) and the extent of bond cleavage of the leaving group ( $\mathrm{Cl}$ ) at the TS is rather low. The difference in the magnitude, i.e. a lower rates of solvolysis of 1 than of solvolysis of diphenylphosphinyl chloride reflects that, under similar conditions, the $\mathrm{P}=\mathrm{S}$ group favours the $\mathrm{Cl}$-bonded nucleofuge $\left(\mathrm{Cl}^{-}\right)$ expulsion less than the $\mathrm{P}=\mathrm{O}$ group.

Phosphate systems are more reactive than their thiophosphate counterparts by one or more orders of magnitude, ${ }^{1+4}$ while phosphinate systems are less sensitive to $\mathrm{S}$ substitution in the $\mathrm{P}=\mathrm{O}$ bond, ${ }^{15}$ in accordance with our results. The $\mathrm{P}=\mathrm{O}$ systems are generally more reactive than their $\mathrm{P}=\mathrm{S}$ counters for several reasons, including the so-called thio effect, which is mainly the electronegativity difference between $\mathrm{O}$ and $\mathrm{S}$ which favors $\mathrm{O}$ over $\mathrm{S}$. ${ }^{\text {l6 }}$

Activation parameters for solvolysis of $\mathbf{1}$ are shown in Table 3. The values of $\Delta H^{*}$, and $\Delta S^{\mp}$ were obtained from the slope and intercept, respectively, of Eyring plots, by leastsquares analysis. The $\Delta H^{*}$ values are relatively low whereas the $\Delta S^{*}$ values are large and negative, observations which are consistent with an $\mathrm{S}_{\mathrm{N}} 2$ mechanism. ${ }^{17}$

Halmann ${ }^{18}$ found, for the ethanolysis of the related diethylphosphinyl chloride. Et $\mathrm{POCl}_{2} \mathrm{PO}$ that the specific rate of solvolysis was dependent upon the concentration of the substrate for the range from $2.5 \times 10^{-3}$ to $17 \times 10^{-3} \mathrm{M}$. We found no perturbation of this nature over a threefold variation at our lower concentrations $\left(0.5 \sim 2 \times 10^{-3} \mathrm{M}\right)$ of diphenylthiophosphinyl chloride undergoing solvolysis in ethanol and $80 \%$ or $50 \%$ ethanol, Table 2 . Similarly, in previous work, we found no concentration dependent perturbation for solvolyses of diphenylphosphinyl chloride $\left(\mathrm{Ph}_{2} \mathrm{POCl}, 2\right){ }^{7}$ or chlorodiphenylphosphine $\left(\mathrm{Ph}_{2} \mathrm{PCl}, 3\right)^{11}$

The solvolysis of organophosphorus halides has been the subject of several studies. At tetracoordinated phosphorus. reactions with nucleophilic reagents were found to usually proceed by bimolecular mechanisms. ${ }^{19}$ Pentacovalent intermediates were most frequently proposed. ${ }^{20}$ Occasionally, unimolecular mechanisms, with a rate determining dissociation of the phosphorus-halogen bond have been postulated. ${ }^{21,22}$

A useful tool for quantitatively estimating the rate-controlling influence of nucleophilic participation by solvent during a solvolysis reaction involves the application of the extended Grunwald-Winstein equation, eq. (1).$^{5-7}$ Appli- cation of eq. (1) to the solvolyses of 1 led to only moderately good correlations, with dispersal for different binary mixtures. For 29 solvents, values were obtained of $1.03 \pm 0.08$ for $l, 0.66 \pm 0.05$ for $m$, and -0.06 for $c$; the standard error of the estimate was 0.08 , and the $R$ value was 0.933 . Inspection of the plot corresponding to this correlation (Figure 1) showed that the four data points for solvolysis in TFEethanol mixtures lay below the plot. Recalculation with omission of these points led to values for $l$ of $1.00 \pm 0.04$, for $m$ of $0.64 \pm 0.03$, and for $c$ of 0.03 (Fig. 1); the standard error of the estimate was 0.04 , and the $R$ value was 0.983 . Inspection of Figure 1 shows the considerable deviation for the four solvolyses in TFE-ethanol mixtures. Also, in earlier correlations of other solvolyses, data points for these TFEethanol solvent systems usually lay below the correlation line.$^{23.26}$ The sensitivity values, $l$ and $m$, and the goodnessof-fit parameters are reported in Table 4 , where they can be compared with literature values for related substrates.

The $l$ and $m$ values obtained are very similar to those recently reported, after an analysis in terms of eq. (1), for the specific rates of solvolysis of $N, N, N_{2}^{*} N^{\prime}$-tetramethyldiamidophosphorochloridate $(l=1.20 \pm 0.07, m=0.69 \pm 0.04){ }^{6} p$ methylbenzenesulfonyl chloride $(l=1.25 \pm 0.15, m=0.62 \pm$ $0.04),{ }^{, 7}$ and p-methoxybenzenesulfonyl chloride $(l=1.10 \pm$ $0.17, m=0.61 \pm 0.04)^{.7}$ The conclusions from studies of nucleophilic attack at the sulfur of arenesulfonyl chlorides are closely related to those for attack at the phosphorus of $N, N, N_{2}^{\prime} N^{\prime}$-tetramethyldiamidophosphorochloridate, with the initial suggestions of the operation of $S_{v} 1$-type mechanisms ${ }^{6}$ now considered highly unlikely to be correct. Recent inter-

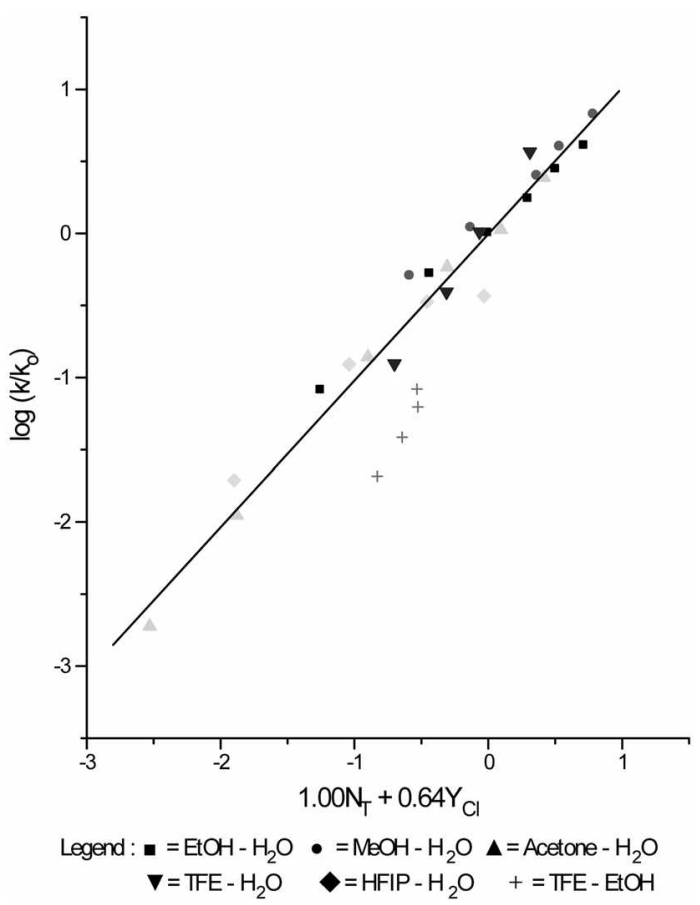

Figure 1. Plot of $\log \left(k i k_{c}\right)$ for solvolyses of diphenylthiophosphinyl chloride at $55.0^{\circ} \mathrm{C}$ against $\left(1.00 \mathrm{~N}_{\mathrm{T}}+0.64 \mathrm{Y}_{\mathrm{C}}\right)$. The TFE-EtOH points are not included in the calculation of the regression line. They are included in the plot to show the extent of their deviation from the line. 
Table 4. Coefficients from the extended Grunwald-Winstein equation (1) correlations of the specific rates of solvolysis of diphenylthiophosphinyl chloride (Ph.PSCl. 1) at $55.0^{\circ} \mathrm{C}$ and a comparison with the corresponding values for other solvolytic displacements of chloride ion from phosphorus (V)

\begin{tabular}{|c|c|c|c|c|c|}
\hline Substrate & $\mathrm{n}^{*}$ & $l^{h}$ & $m^{h}$ & $c^{h}$ & $\mathrm{R}^{\prime}$ \\
\hline $\mathrm{Ph}=\mathrm{PSCl}$ & 29 & $1.03 \pm 0.08$ & $0.66=0.05$ & $-0.06 \pm 0.08$ & 0.933 \\
\hline $\mathrm{Ph} \_\mathrm{PSCl}^{\prime}$ & 25 & $1.00 \pm 0.04$ & $0.64=0.03$ & $0.03 \pm 0.04$ & 0.983 \\
\hline $\mathrm{Pl}_{2} \mathrm{POCl}^{*}$ & 31 & $1.44 \pm 0.13$ & $0.58=0.09$ & $0.15 \pm 0.14$ & 0.920 \\
\hline $\mathrm{Pl} \_\mathrm{POCl}{ }^{\prime}$ & 27 & $1.42 \pm 0.10$ & $0.54=0.07$ & $0.32=0.11$ & 0.956 \\
\hline $\mathrm{Ph} \times \mathrm{PCl}^{t}$ & 29 & $1.31 \pm 0.14$ & $0.51=0.09$ & $0.12 \pm 0.14$ & 0.899 \\
\hline $\mathrm{Ph} \cdot \mathrm{PCl}^{d}$ & 25 & $1.25 \pm 0.09$ & $0.46=0.06$ & $0.24 \pm 0.09$ & 0.954 \\
\hline$(\mathrm{MeO}) \pm \mathrm{POCl}^{5}$ & 22 & $1.36 \pm 0.23$ & $0.54=0.13$ & $-0.02 \pm 0.17$ & 0.844 \\
\hline$(\mathrm{MeO})_{2} \mathrm{POCl}{ }^{\text {lig }}$ & 18 & $1.24 \pm 0.14$ & $0.45=0.08$ & $0.18=0.11$ & 0.941 \\
\hline$(\mathrm{MeO})$ PSCl? & 31 & $1.21 \pm 0.10$ & $0.60=0.04$ & $0.22 \pm 0.07$ & 0.943 \\
\hline$(\mathrm{MeO})_{2} \mathrm{PSCl}$ & 28 & $1.16 \pm 0.08$ & $0.55=0.03$ & $0.30 \pm 0.06$ & 0.966 \\
\hline$\left(\mathrm{Me}_{2} \mathrm{~N}\right)_{2} \mathrm{POCl}^{h}$ & 31 & $1.20 \pm 0.07$ & $0.69=0.04$ & $0.03 \pm 0.32$ & 0.958 \\
\hline$\left(\mathrm{Me}_{2} \mathrm{~N}\right){ }_{2} \mathrm{POCl} \mathrm{l}^{j / h}$ & 27 & $1.14 \pm 0.05$ & $0.63=0.03$ & $0.17 \pm 0.21$ & 0.982 \\
\hline$(\mathrm{PhO})_{2} \mathrm{POCl}^{i}$ & 38 & $1.72 \pm 0.18$ & $0.68=0.06$ & $0.42 \pm 0.15$ & 0.885 \\
\hline$\left(p-\mathrm{ClC}_{4} \mathrm{H}_{\downarrow} \mathrm{O}\right)_{2} \mathrm{POCl}^{i}$ & 31 & $1.79 \pm 0.20$ & $0.58=0.08$ & $0.11 \pm 0.18$ & 0.863 \\
\hline
\end{tabular}

"Number of Jata points. "From eq. 1. COrrelation coefficient. "Data points for TFE-ethanol (T-E) mixtures excluded. "From ref. $7 .{ }^{\prime}$ From ref. $11 .{ }^{4}$ From ref. 5. "From ref. 5. 'From ref. 4 .<smiles></smiles>

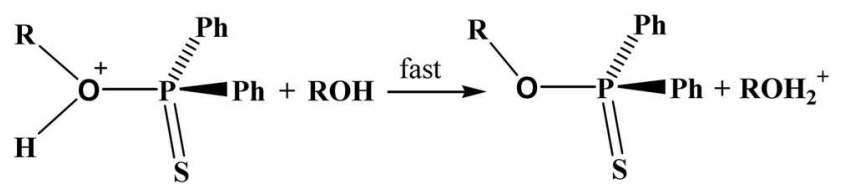

Scheme 1

pretations for attack at sulfur have been in terms of bimolecular attack, but with some degree of uncertainty as to whether this is concerted or stepwise. Bentley, Jones and $\mathrm{KoO}^{28}$ suggested that both mechanisms can operate, with the concerted mechanism favored in the more polar solvents. A tairly recent review ${ }^{2 y}$ favored an interpretation in terms of a concerted bimolecular displacement $\left(\mathrm{S}_{\mathrm{N}} 2\right)$ mechanism. involving an attack by solvent at sulfur. Our analyses are considered to be consistent with such an explanation. The close similarity of both the / and the $m$ values for attack at sulfiur to those for the attack at the phosphons of 1 gives an indication that the solvolyses of 1 could also be concerted, Scheme 1 .

We found that the use of $\mathrm{N}_{\mathrm{T}}$ values in conjunction with $\mathrm{Y}_{\mathrm{Cl}}$ values leads to acceptable correlations, with $l$ and $n$ values similar to those obtained in analyses of the specific rates of solvolysis for other entries within Table 4 . The major difference is a somewhat smaller $l$ value for the solvolyses of $\mathbf{1}$, possibly reflecting a decreased nucleophilic participation at the transition state due to reduced interaction involving the phosphinyl sulfur $(\mathrm{P}=\mathrm{S})$ relative to the $\mathrm{P}=\mathrm{O}$ bond, containing a more electronegative oxygen.

In methanol $(\mathrm{MeOH})$ and methanol-d (MeOD) a kinetic solvent deuterium isotope effect $\left(k_{\mathrm{MeOH}} / k_{\mathrm{MeOD}}\right)$ of $1.83 \pm$ 0.05 at $55.0^{\circ} \mathrm{C}$ is observed (Table 1 ). This is in the range of values from $1.58 \pm 0.05$ to $2.31 \pm 0.07$ that was observed ${ }^{30}$ for the corresponding methanolyses of a series of benzenesulfonyl chlorides at $25.0^{\circ} \mathrm{C}$, reactions believed to be $\mathrm{S}_{\mathrm{N}} 2$ in character. Similarly, the methanolyses of meta- and parachlorobenzyl chloride and of para-nitrobenzyl chloride, believed to be $\mathrm{S}_{\mathrm{v}} 2$ in character, show values in the $1.49 \pm$ 0.05 to $1.89 \pm 0.07$ range $^{31}$ Indications are that a value in these ranges can be considered as good supporting evidence for the postulation of an $S_{\mathfrak{v}} 2$ mechanism for a methanolysis.

\section{Conclusions}

The solvolyses of 1 proceed rather rapidly at $55.0^{\circ} \mathrm{C}$ and the progress of reaction as a function of time can be conveniently monitored using a rapid-response conductivity technique. For five typical solvents, activation parameters were determined and the large negative entropies of activation are consistent with a bimolecular process. Kinetic solvent deuterium isotope effects for the solvolyses $\left(k_{\mathrm{MeOH}} /\right.$ $k_{\text {MeeD }}$ ) are also consistent with a bimolecular process.

Application of the extended Gnunwald-Winstein equation (eq. 1 ) in 25 solvents led to an $l$ value of 1.00 and an $m$ value of 0.64 (correlation coefficient of 0.983 ). These values are shown (Table 4) to be similar to previously determined values for nucleophilic attack by solvent at phosphorus(V). They are, also, very close to literature values for the solvolyses of sulfonyl chlorides. Previously-studied solvolytic displacements at phosphorus or sulfiur have usually been proposed to follow an $\mathrm{S}_{\mathrm{N}} 2$ pathway, and such a pathway is also proposed for the solvolyses of 1 (Scheme 1).

\section{Experimental}

The purification of acetone, methanol and ethanol were carried out as previously described. ${ }^{32}$ The purification of 1,1,1,3,3,3-hexafluoro-2-propanol, ${ }^{33}$ and 2,2,2-trifluoroethano ${ }^{34}$ were also carried out by use of previously reported procedures. Water was used after distillation. Diphenylthio- 
phosphinyl chloride was commercially available from Wako Pure Chemicals Industries, Ltd. The substrate did not react with the pure acetonitrile within the stock solution.

Kinetic runs were performed with $10 \mu \mathrm{L}$ of the stock solution of the substrate $(1 \mathrm{M})$ and $5 \mathrm{~mL}$ of the reaction solvent. All kinetic runs were performed, at least, in duplicate. The reaction cell was washed with water and acetone several times and dried prior to each run. A $5 \mathrm{~mL}$ portion of solvent was added to the reaction cell and allowed to sit for a few minutes until it reached a temperature equilibrium with the constant temperature bath. A $10 \mu \mathrm{L}$ portion of the stock solution was then added and the reaction cell was shaken vigorously. The change of the conductance in the reaction with time was saved in the computer as a data file.

Rates were measured conductimetrically at $55.0^{\circ} \mathrm{C}$. All kinetic measurements were carried out in a constant temperature bath maintained within $\pm 0.05^{\circ} \mathrm{C}$. The conductivity bridge used in this work was a self-made computer automatic A/D converter conductivity bridge. First-order solvolysis rate coefficients $\left(k_{\text {obs }}\right)$, with the solvent in large excess. were determined by a curve fitting analysis of the computer data with a modified version of the Origin Program, which fits conductance vs. time data to the equation, $A=A_{s}+\left(A_{0}-\right.$ $\left.A_{\infty}\right) \exp \left(-k_{0 \mathrm{bs}} \times t\right)$, where $A$ is the observed conductivity and $A_{s,} A_{0}-A_{s,}$ and $k_{0 \text { bs }}$ are iteratively optimized to achieve the best possible least-squares fit.

Acknowledgments. One of the authors (Koh, H. J.) is thankful to Northern Illinois University (U.S.A) and Professor Dennis $X$. Kevill for his hospitality and devoted advice during preparation and revision of this paper.

\section{References}

1. (a) Corbridge, D. E. C. Phosphorts-An Ontline of its Chemistr: Biochemistr: and Uses, $5^{\text {th }}$ ed; Elsevier: Amsterdam, 1995; Chapter 11 . (b) Willians, A Concerted Organic and Bio-Organic Mechanishts: CRC Press: Boca Raton, 2000. (c) Hudson, R. F. Strtcture and Mechanisn on Organophosphtorts and Chemistry; Academic Press: New York, 1965.

2. Thatcher, G. R. J.; Luger, R. K. Adv Phs. Org. Chem. 1989, $35,99$.

3. (a) Skoog, M. T.; Jencks, W. P. J. Am. Chem. Soc. 1984, 106 , 7597. (b) Boume, N.; Williams, A. J. Am. Chem. Soc. 1984, I06, 7591. (c) Kirby, A. J.; Varroglis, A. G J. An. Chem. Soc. 1967, 89, 415 . (d) Friedman, I. M.; Freeman, S.; Knowles, T. R. $J$. Am. Chem. Soc. 1988, 110, 1268. (e) Bourne, N.; Chrystiuk, E; Davis, A. M.; Williams, A. J. Am. Chem. Soc. 1988, 110, 1890. (f) BaSaif, S. A.; Waring, M. A.; Willians, A. J. Am. Chem. Soc. 1990 , 1I, 8115. (g) Hengge, A. C.; Edens, W. A.; Elsing, H. J. Am. Chem. Soc. 1994, 116, 5045. (h) Hoff, R. H.; Hengge, A. C. J. Org. Chent 1998, 63, 6680. (i) Guha, A. K.; Lee, H. W.; Lee, I. $J$. Chem. Soc., Perkin Trons. 2 1999, 765. (j) Hoque, Md. E. U.; Dey, N. K.; Guha, A. K.; Kim, C. K.; Lee, B.-S.; Lee, H. W. Bull. Korean Chem. Soc. 2007, 28, 1797.

4. Bentley, T. W; Ebdon, D.; Llewellyn, G; Abduljaber, M. H.; Miller, B.; Kevill, D. N. J. Chent. Soc. Dalton Trans. 1997, 3819.

5. Kevill, D. N.; Carver, J. S. Org. Biontol. Chem. 2004, 2, 2040.

6. Kevill, D. N.; Miller, B. J. Org. Chent 2002, 67, 7399.

7. Kevill, D. N.; Koh, H. J. J. Phrs. Org. Chem. 2007, $20,88$.

8. Winstein, S.; Grunwald, E.; Jones, H. W. J. Am. Chem. Soc. 1951, 73,2700

9. (a) Grunwald, E.; Winstein, S. J. Ant Chent. Soc. 1948, $70,846$. (b) Bentley, T. W.; Llewellyn, G. Prog. Phns. Org. Chem. 1990, 17, 121. (c) Kevill, D. N.; D'Souza, M. I. I. Chem. Res. Sinop. 1993, 174. (d) Bentley, T. W. Carter, G. E. J. An. Chem. Soc. 1982, 104, 5741. (e) Koo, 1. S.; Bentley, T. W.; Kang, D. H.; Lee, I. J. Chem. Soc., Perkin Trans. $21991,296$.

10. (a) Kevill, D. N.; Anderson, S. W. J. Org. Chem 1991, 56, 1845 (b) Kevill, D. N. In Adrances in Otantitative Structure-Propent Relationships; Charton, M., Ed.; JAI Press: Greenwich, CT, 1996, Vol. 1, pp 81-11s.

11. Koh, H. J.; Kang, S. J.; Kevill, D. N. Phosphorus, Sulfit; and Silicon 2008, 183,364 .

12. Bentley, T. W.; Ebdon, D. N. J. Phis. Org. Chem. 2001, 14, 759

13. Koh, H. I.; Han, K. L.; Lee, H. W; Lee, I. I. Ong. Chem. 1998, 63, 9834.

14. (a) Neinysheva, A. A.; Savchik, V.; Ermolaeva, M. V.; Knunyants, I. L. Bull. Acad. Sci. USSR Div. Chem. Sci. (Engl Transl) 1968, 2104. (b) Ketelaar, J. A. A.; Gresmann, H. R.; Koopmans, K. Recl. Tran Chim Pals-Bas. 1952, 71, 1253. (c) Chlebowski, J. F.; Coleman, J. E. J. Biol. Chem. 1974, 247,7192.

15. (a) Cook, R. D.; Farah, S.; Ghawi, L.; Itani, A.; Rahil, J. Can. J. Chen. 1986, 64, 1630. (b) Bel'skii, V. E.; Bezzubova, N. N.; Akamsin, V. D.; Eliseenkov, V. N.; Rizpolozhenskii, N. I.; Puduvik, A. N. Dokl. Akad. Nank. SSSR 1971, 197, 85; Eng. Trans. p 171. (c) Onyido, I.; Swierczek, K.; Purcell, J.; Hengge, A. C. J. An. Chen. Soc 2005, 127, 7703. (d) Douglas, K. T; Williams, A. J. Chem. Soc. Perkin Trans. 2 1976, 515. (e) Lm, I. H.; Akhtar, K.; Shin, Y. H.; Han, J. Y. J. Org. Chem. 2007, 72 3823. (f) Cook, R. D.; Daouk, W. A.; Haij, A. N.; Kabbani, A.; Kurku, A.; Samalha, M.; Shayban, F.; Tanielian, O. V. Can. $J$. Chem. 1986, 64, 213 .

16. (a) Hengge, A. C.; Onyido, I. Cum: Org. Chem. 2005, 9, 61. (b) Omakor, J. E.; Onyido, I; VanLoon, G W.; Buncel, E. J. Chen. Soc., Perkin Trans. 2 2001, 324. (c) Gregersen, B. A.; Lopez, X; York, D. M. J. Am. Chem. Soc. 2003, 125,7178 . (d) Hondal, R. J.; Bruzik, K. S.; Zhao, Z; Tśai, M. D. I. Am. Chem. Soc. 1997, 119, 5477.

17. Lee, I.; Sung, D. D.; Lhm, T. S.; Ryu, Z. H. J. Chem. Soc, Perkin Trans. $21989,1697$.

18. Halmann, M. Phosphorus Sulfur 1988, 40, 251.

19. (a) Dostrovsky, 1.; Halmaun, M. J. Chem. Soc. 1953, 502. (b) Dostrovsky, I.; Halmann, M. J. Chem. Soc. 1956, 1004. (c) Corriu, R. J. P. Phosphorus Sulfur 1986, 27, 1. (d) Lanneau, G. F. Phosphoris Sitfir 1986, 27, 43 .

20. Westheiner, F. H. Acc. Chen. Res: 1968, 1,70.

21. Hall, H. K. Jr, J. Org. Chen, 1956, 21, 248.

22. Wadsworth, W. Ir. Horton, H. J. Am. Chem. Soc. 1970, $92,3785$.

23. Kevill, D. N.; D`Souza, M. J. J. Chem. Soc., Perkin Trans. 21997. 1721 .

24. Kevill, D. N.; Kim, J. C.; Kyong, J. B. J. Chem. Res. Sinop. 1999 , 150.

25. Kevill, D. N.; D'Souza, M. J. J. Org. Chen. 1998, 63, 2120.

26. Kyong, J. B.; Park, B. C.; Kim, C. B.; Kevill, D. N. J. Org. Chem. $2000,6.5,8051$.

27. Kevill, D. N.; D'Souza, M. J. Collect. Czech Chem. Commun. $1999,64,1790$.

28. Bentley, T. W.; Jones, R. O; Koo, I. S. J. Chen. Soc. Perkin Trons. 21994,753

29. Gordon, 1. M.; Maskill, H.; Ruasse, M.-F. Chem. Soc. Rev 1989, I\&, 123.

30. Koo, l. S.; Lee, I.; Ol, J. U.; Yang, K. Y.; Bentley, T. W. J. Phis. Org. Chen. 1993, 6, 223.

31. Lee, I.; Koh, H. I; Park, Y. S.; Lee, H. W. J. Chen. Soc, Perkin Trans. $21993,1575$.

32. Kevill, D. N.; Kolwyck, K. C.; Weitl, F. L. J. Am. Chem. Soc. $1970,9 \geq, 7300$

33. Bentley, T. W.; Bowen, C. T.; Parker, W.; Watt, C. I. F. J. Chem. Soc., Perkin Trans. 2 1980, 1244.

34. Rappoport, Z.; Kaspi, J. J. An. Chen. Soc. 1974, 96, 4518. 